\title{
BRAZILIAN JOURNAL OF IMPLANTOLOGY AND HEALTH SCIENCES
}

ISSN 2674-8169

This work is licensed under an international creative commons attribution 4.0 license.

\section{DOI (CROSRREF)}

https://doi.org/10.36557/2674-

8169.2020v2n2p1-12

\section{AFFILIATED INSTITUTION}

1- Professora Adjunta I Disciplinas de Estomatologia, Clinica Integrada e Pacientes Especiais -Departamento de Estomatologia CCS - UFSC; Especialista em Odontopediatria $\mathrm{ABO} / \mathrm{SC}$; Mestre e Doutora pela UFSC; Rua Duarte Schutel, 181/ 422, Everest Park, Centro-88015-640, Florianópolis/SC.

2- Professor das Disciplinas de Patologia Bucal, Semiologia e Propedêutica da UNOESC. Especialista em ImplantodontiaCEPID/UFSC; Mestrando em Epidemiologia em saúde Coletiva-UNOESC.

\section{KEY WORDS}

implantology, Oral Rehabilitation, Pediatric Dentistry...

\section{Ana Paula Soares Fernandes'; Márcio Antônio Battistella ${ }^{2}$ \\ Corresponding Author: Ana Paula Soares Fernandes}

\section{REVIEW ARTICLE}

Dental Implants in Pediatric Dentistry: A Literature Review.

The use of osseointegrated implants has been increasingly widespread in the adult population, however in children there is a certain lack in the literature on the application of this technique. The bone growth and development factor must be well analyzed, and the pediatric dentist must be able to suggest the use of this treatment option for oral rehabilitation, when necessary. This article discusses bone growth and development of the craniofacial region, presents relevant aspects of the literature and discusses the use of this technique in pediatric patients. 


\section{INTRODUCTION}

The use of osseointegrated implants has been increasingly widespread in the adult population. The success of these implants depends on a surgical / prosthetic protocol followed correctly, always taking into consideration the patient's general health, adequate bone quantity, wellexecuted surgical technique, prosthetic planning and satisfactory oral health [1].

The use of implants in children is less frequent and has been widely discussed because these patients are in the bone development stage. The scarcity of clinical cases reported in the literature and controversies in the use of implants at this stage also increase the discussion [2].

In the clinical routine of the dental surgeon, one can come across situations in which osseointegrated implants could be a great treatment option in pediatric patients. As an example, we mention: partial or total anodontics resulting from syndromes such as Ectodermal Dysplasia and Down's Syndrome; oligodontias: early losses in cases of extensive caries lesions; advanced periodontal disease or trauma [3].

Several studies have been done in patients with ectodermal dysplasia. Therefore, the objectives of this work are: to contribute to the study on the use of osseointegrated implants in pediatric patients, to facilitate the understanding of the pediatric dentist in the area of implantology so that he is able to indicate, when necessary, the use of this technique.

\section{LITERATURE REVIEW}

\section{Craniofacial Growth}

It is very important to know the growth and development of the nasomaxillary complex and the mandible in order to be successful in the technique of implant placement in pediatric patients [1].

In order to understand growth in any area of the body, it is necessary to understand some concepts: growth sites or places; type of growth occurring in these locations and determining or controlling factors for this growth [2].

According to Proffit (1995), it is convenient to divide the craniofacial complex into different types of growth: cranial vault (bones that cover the upper and outer surface of the brain; 
cranial base (bones that serve as the brain floor and which is also a dividing line between skull and face; nasomaxillary complex (nose, maxilla and associated small bones; and mandible).

\section{Growth of the Nasomaxillary Complex}

The growth of the maxilla occurs in two ways: by apposition (the position of the bones that articulate the maxilla to the skull) and by superficial remodeling [2].

The growth pattern of the face requires it to grow "independently under the skull", which means that the maxilla needs to move, by growth, a considerable distance down and forward in relation to the skull and the cranial base. The growth of soft tissues occurs by taking the maxilla forward and downward, opening space in the upper and posterior sutural connection, and the new bone is added on both sides of the suture. The sutures remain the same thickness, and the various processes of the maxilla are longer. Bone apposition occurs on both sides of the suture, and then the bones that articulate with the maxilla also become wider. Although the maxilla grows forward and downward, its frontal surface is remodeled and the bone removed from most of the anterior surface. It is noteworthy that the largest portion of the anterior surface of the maxilla is the resorption area, not the apposition area. The total change in growth is the result of the translation of the maxilla forwards and downwards and of a simultaneous surface remodeling. The entire nasomaxillary bone complex moves down and forward in relation to the skull, as shown in Figure 1 [1].

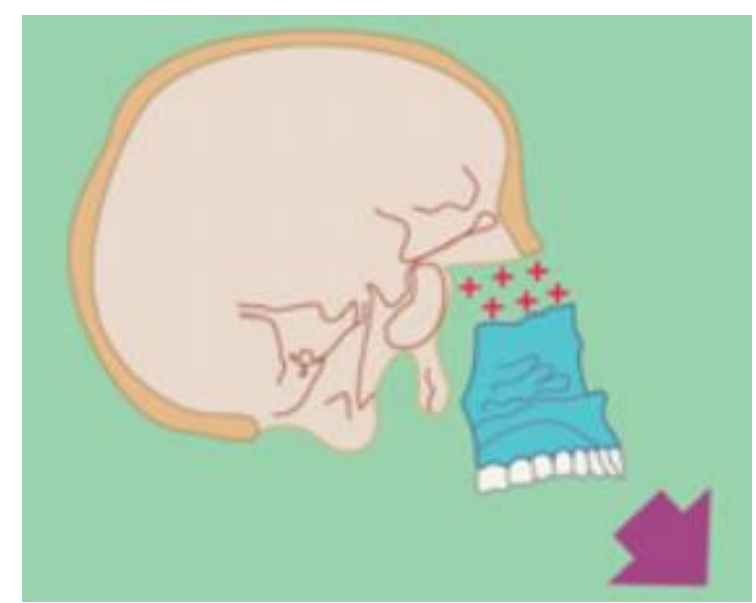

FIGURE 1: Growth of the maxilla (Altered from Enlow,1993)

In 1993, Enlow described the jaw as a platform on wheels, moving forward, while, at the same time, its surface is being reduced on the anterior side and built later, moving in space opposite the direction of total growth.

Bjork et al., In 1997, and Wilcox, in 2003, stated that the direction of maxillary growth is highly variable. During the period of primary dentition, passive growth is very important. One third 
of the estimated passive growth is complete after the age of seven. The other two thirds occur by enlarging the maxilla itself, which must be observed carefully.

As the growth direction is variable, transverse maxillary skeletal changes, vertical skeletal changes, transverse maxillary dental changes, anteroposterior maxillary dental changes can occur [3].

Care must be taken when choosing to place implants in the maxilla of patients in bone development. According to Andreasen (1993), the implants placed in the jaws in growth do not erupt like natural teeth.

They behave like ankylosing teeth, resulting in infra-occlusion. Malmgrem et al. (1993) stated that the greater the residual growth, the greater the infra-occlusion of the crowns on the implant.

In contrast to the maxilla, both endochondral and periosteum activities are important in the growth of the mandible. There is cartilaginous tissue covering the condyle of the mandible in the temporomandibular joint. However, this cartilage is not the same as that of the epiphyseal disc or a synchondrosis, as it contains hyperplasia, hypertrophy and endochondral replacement. All other areas of the mandible are formed and grow by direct apposition to the surface and remodeling [1].

The length of the mandible increases almost exclusively due to postero-superior growth of the condyle and posterior growth of the branch, as shown in Figure 2.

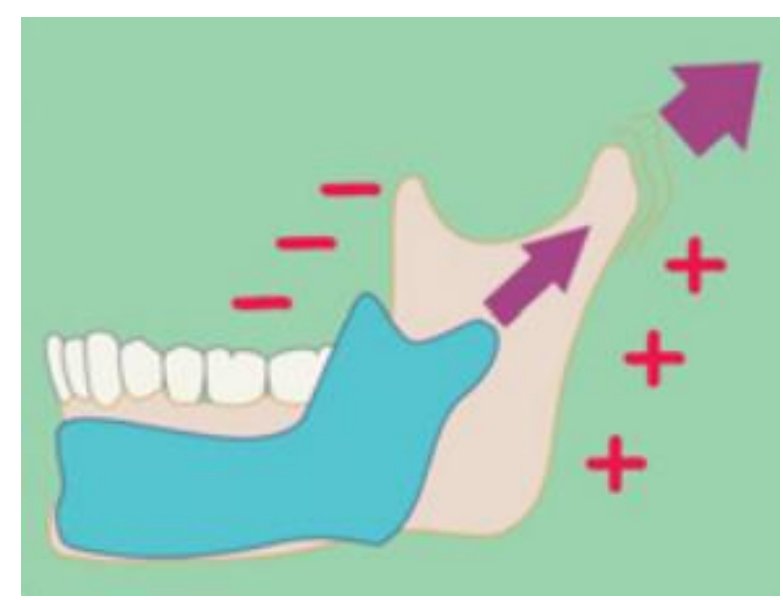

FIGURE 2: Posterior superior growth of the condyle and posterior branch growth [4].

The increased prominence of the chin is the result of reabsorption of the labial cortex above it. According to Cieluck (1999), to allow the molars to erupt, the body of the mandible increases in length, by resorption in the anterior portion of the branch and apposition in the posterior one. The height of the branch increases from 1 to $2 \mathrm{~mm}$ per year. Due to the "V" shaped growth model (Enlow, 1993), there is an increase in the posterior width of the 
mandible, as shown in Figure 2. As a result, the anterior mandibular width stabilizes relatively early and only increases weakly, due to appositional growth.

In childhood, the branch is located approximately where the first deciduous molar will erupt. The progressive posterior remodeling creates a space for the deciduous second molar, and then for the sequential eruption of the permanent molars. More frequently, this growth ceases before sufficient space is obtained for the eruption of third molars, which become impacted on the branch [5].

The success of implant placement in the mandible is favored by the absence of a complicated suture, as occurs in the maxilla [6].

As transverse growth in the region of the lower incisors and canines ceases early, mandibular implants have, on average, a better prognosis in young patients than those placed in other areas of the mandible.

\section{Placement of Implants in a Pediatric Patient}

Some factors must be observed when opting for the use of implants in a pediatric patient, among them, there is the anatomical aspect, because the anatomical structures, such as the jaws, are consequently small according to Weide (1992). It should also be noted that, in children, the capacity for healing, regeneration, remodeling, and adaptation to function is greater [7].

The use of implants in pediatric patients is infrequent, due to the patient's bone growth. Brånemark (1996) reported that there is no ideal chronological age for implant placement. Each patient should be observed individually and from there, choose whether or not to use osseointegrated implants.

Authors such as Mackie et al. (1993) do not recommend this technique before 15 years of age. Other authors such as Lekmon (1993), Cronin, Ranly (1993) affirmed that one must wait for the end of bone development for the placement of implants. Oesterle et al. (1994) suggested that osseointegrated implants should be placed after the age of 15, however, when placed in the growth phase, the prostheses should be monitored until this growth has ended.

Several authors have reported their experience in using this technique. In 1991, Berdengal obtained promising results in patients aged 5-6 years. In 1993, Lederman was successful in $83 \%$ of the implants he placed in pediatric patients. In 1999, Junge opted for implant placement in 12-year-old patients with agenesis of lateral incisors. Berdengal et al., 1991; Cronin et al., 1991; Guckes et al., 1991, Smith et al., 1993 and Kupitzky et al., 1995, indicated the use of implants in pediatric dentistry in cases of ectodermal dysplasia. Cieluck (1999) indicated this technique in the following cases: congenital absences of teeth in growing patients, which involve hypodontias, oligodontias, anodontias and agenesis; systemic 
conditions involving malformations and dental absences, patients with Down Syndrome; in cases of early tooth extractions due to extensive caries, and finally in cases of bone and tooth loss due to trauma.

In 2004, Heij et al. Affirmed that it is evident that facial growth can be very compromising for oral implants, but more and more implants are inserted in young patients, especially after trauma to the upper incisor.

The controversies related to the placement of osseointegrated implants in pediatric patients can be seen briefly in the table below.

TABLE 1: Comparative chart of authors who recommend or not to place osseointegrated implants in pediatric patients.

\begin{tabular}{|c|c|c|c|}
\hline \multicolumn{2}{|c|}{ Recommend } & \multicolumn{2}{|c|}{ Not Recommend } \\
\hline Author & Justification & Author & Justification \\
\hline $\begin{array}{l}\text { Sillman (1964) } \\
\text { (região anterior) }\end{array}$ & $\begin{array}{l}\text { Shows satisfactory result } \\
\text { in the midline of the } \\
\text { mandible }\end{array}$ & $\begin{array}{l}\text { Sillman (1964) } \\
\text { (região posterior) }\end{array}$ & $\begin{array}{l}\text { Anterior mandible region } \\
\text { has better prognosis }\end{array}$ \\
\hline Berdengal (1991) & $\begin{array}{l}\text { Promising results in 5-6 } \\
\text { year old patients }\end{array}$ & Mackie (1993) & $\begin{array}{l}\text { Must not be placed before } \\
\text { age } 15\end{array}$ \\
\hline Lederman (1993) & $\begin{array}{l}83 \% \text { success in pediatric } \\
\text { implants }\end{array}$ & $\begin{array}{l}\text { Lekmon, Cronin, Ranly } \\
\text { (1993) }\end{array}$ & Wait for bone growth \\
\hline Oesterle (1994) & Only after 15 years & Koch et al (1996) & $\begin{array}{l}\text { Wait for craniofacial growth } \\
\text { to avoid adverse effects: loss } \\
\text { of implants in places where } \\
\text { there would be an } \\
\text { expectation of bone } \\
\text { resorption, and burial of } \\
\text { implants in areas of bone } \\
\text { apposition }\end{array}$ \\
\hline $\begin{array}{l}\text { Berdengal, Cronin, } \\
\text { Guckes (1991), Smith } \\
\text { et al (1993), Kupitzky } \\
\text { et al, 1995, Cieluck } \\
\text { (1999) }\end{array}$ & $\begin{array}{l}\text { Cases of Ectodermal } \\
\text { Dysplasia, Down's } \\
\text { Syndrome, and Early } \\
\text { Extractions }\end{array}$ & & \\
\hline Junge (1999) & $\begin{array}{l}\text { Agenesis of Lateral } \\
\text { Incisions }\end{array}$ & & \\
\hline
\end{tabular}

\section{DISCUSSION}


The placement of osseointegrated implants in pediatric dentists has been widely discussed and in some studies it is possible to observe some controversies regarding its use or not. Many authors recommend that the implants are not placed before the age of $15[9,10]$.

Transverse growth in the region of the lower incisors and canines ends early. Thus, implants placed in the midline of the mandible have a better prognosis in young patients thanthose placed in the posterior region $[11,35]$.

In contrast to the maxilla, both endochondral and periosteum activities are important in the growth of the mandible. There is cartilaginous tissue covering the condyle of the mandible in the temporomandibular joint. However, this cartilage is not the same as that of the epiphyseal disc or a synchondrosis, as it contains hyperplasia, hypertrophy and endochondral replacement. All other areas of the mandible are formed and grow by direct apposition to the surface and remodeling [12,34].

An implant placed in the posterior region of the maxilla $[13,14]$ could become buried in its coronal portion, while its apical portion could become exposed by the remodeling of the nasal floor. They also reported the possibility of loss of implants placed in the anterior region of the maxilla due to the reabsorption of the infradental fossa and nasal floor $[13,14]$.

Implants placed in the growing jaws do not erupt like natural teeth. They behave like ankylosing teeth, resulting in infra-occlusion [15].

The greater the residual growth, the greater the infra-occlusion of the crowns on the implant [16]. In 1991, Berdengal et al. reported having obtained promising long-term results in the use of implants in patients aged 5-6 years and stated that the prerequisite for the treatment of these patients would be that the alveolar crest of the mandible was low or absent and that only small growth changes were expected. They also recommended that overdentures be used to allow prosthetic reconstructions adapted to growth [16].

Fixed prostheses on implants [17], crossing the midline of the jaws, especially the upper jaw, may be inappropriate due to the risk of not allowing growth.

Implant therapy in children at an early age [18], in cases of total absence, as can occur in ectodermal dysplasia. He also suggested that for the manufacture of the prosthesis on implants in pediatric dentistry, the ideal would be for the prosthetist to post the definitive prosthetic treatment, opting for a transitional prosthesis, until the patient is old enough.

A generalized clinical guide $[18,36]$ would be not to place implants in children until the craniofacial growth has ended, in order to avoid adverse effects, such as the burial of 
osseointegrated implants in areas of bone apposition and the possible loss of implants in locations where bone resorption would be expected.

There is no ideal chronological age for implant placement [19,37]. Each patient must be observed individually and from there, choose whether or not to use osseointegrated implants

The use of implants in children with ectodermal dysplasia syndrome $[20,21,22,23,38,38]$.

The use of osseointegrated implants during the development of anodontic children $[24,40]$, as well as in cases of irradiated tumors in the mandibles, facial malformations, infections and early tooth loss. He also stated that a well-fixed implant prosthesis not only allows the restoration of facial height, but also aesthetics and self-esteem, as well as dental function.

The success of implant placement in the mandible is favored by the absence of a complicated suture, as in the maxilla. Due to the fact that the symphysial suture begins to close for a few months after birth, there is no danger of implant surgery traumatizing the growth site and there is little possibility that the prosthesis placed across the midline can limit transverse growth $[25,41]$.

The use of implants in 12-year-old patients with agenesis of lateral incisors, associated with orthodontic treatment, when necessary [26].

Implants placed in the antero-inferior region of patients in bone growth and development maintain their perfectly normal position $[27,42]$. They also recommended a multidisciplinary integration between dentists, surgeons, pediatric dentists and orthodontists for successful treatment.

Overdenture $[28,45]$, can be used as temporary prostheses if the patient needs to postpone the making of the definitive prosthesis.

Brånemark, in 1993, and Cieluck, in 1999, suggested the use of general anesthesia to perform implants in pediatric patients $[29,30,43,44]$.

It is worth emphasizing the importance of knowing the growth and development of the nasomaxillary complex and the mandible in order to achieve success in the technique of implant placement in pediatric patients $[31,46]$.

In 1993, Oesterle proposed that an implant placed in the posterior region of the maxilla could become buried in its coronal portion, while its apical portion could become exposed by the remodeling of the nasal floor. He also reported the possibility of loss. 
Authors such as Lekmon (1993), Oesterle et al. (1993) advocated that the growth model be carefully monitored and that the implants are not installed until growth is finished.

The direction of maxillary growth is highly variable and that during the period of primary dentition, passive growth is very important, with careful observation of the skeletal maxillary changes that may occur $[32,33]$.

It is evident that facial growth can be very compromising for oral implants, but more and more implants are inserted in young patients, especially after trauma to the upper incisor [34].

\section{CONCLUSION}

There is still a shortage in the literature on the placement of implants in children, with the need for longitudinal studies for greater applicability of this technique, in order to obtain real evidence of success or not.

The technique of using implants in pediatric dentistry is basically the same technique recommended for adult patients and the prosthetic part must be meticulously planned.

The use of osseointegrated implants for the purpose of oral rehabilitation in pediatric dentistry is based on a scientific basis for pediatric dentistry to indicate this technique and should be used according to the needs and possibilities of each patient. It is a technique that presents its clinical applicability, but the professional must be safe and aware of the difficulties related to craniofacial growth that guide the use of osseointegrated implants in children.

\section{REFERENCES}

1- Albrektsson T et al. The long-tenn effi cacy of currently used dental implants: a review and proposed criteria of success. Int $\mathrm{J}$ Oral Maxillofac Implantodont 1986; 1:11-25.

2- Albrektsson T et al. State of the art in oral implants. J Clin Periodontol 1991; 18:474-81.

3- Albrektsson T et al. Osseointegrated titanium implants. Requirements for ensuring a long-lasting, direct bone-to-imp1ant anchorage in man. Acta Orthop Scand 1984; 52:155.

4- Andreasen JO, Andreasen FM. Textbook and color Atlas of Traumatic Injuries to the Teeth. Munksgaards Forlag, 1993. 
5- Bergendal B et al. A multidisciplinary approach to oral rehabilitation with osseointegrated implants in clindren and adolescents with mitiple aplasia. Eur J Orthod 1996. In press.

6- Bergendal B et al. A multidisciplinary approach to oral rehabilitation with osseointegrated implants in children and adolescents with multiple aplasia. Eur J Orthodont 1996; Jõnkõnping, p.119- 29.

7- Bergendal B et al. Osseointegrated implants .in the oral habilitation of a boy with ectodermal dysplasia: a case report. Int Dent J 1991; 41(3):149-56.

8- Bjork $A$ et al. Growth of the maxilla in three dimensions as revealed radiographicallyby the implant method. Br J Orthodont 1977; 4:53-64.

9- Bjork A et al. Variations in the Growth Pattern of the Hmnan Mandible: Longitudinal Radiographic Study by the Implant Method. J Dent Res Supplement 1963; 42(1):400-411.

10-Bjork $A$ et al. Prediction of the age of maximum pubertal growth in body heigth. Angle Orthod 1967; 37:134-43.

11-Bjork A, Skieller V. Growth of the maxilla in three dimensions as revealed radiographically by the implant method. British J Orthodont 1975; 4(2):53-64.

12-Brånemark P-I et al. Intra-osseous anchorage of dental prostheses. I. Experimental studies. Scand J Plast Reconstr Surg Hand Surg 1969; 3:81100.

13-Brånemark P-I et al. Osseointegração and its experimental background. J Prosthet Dent 1983; 50: 399-410.

14-Brånemark P-I et al. Osseointegrated Implants in Gorwing Jaws. Int J Oral Maxillofac Implantodont 1993; 8:243-4.

15-Brånemark $P$-l et al. Consensus conference on oral implants in young patients. Stockholm: Forlagshuset Gothia AB; 1996

16-Brook A. An epidemiological study of dental anomalies in English schoolchildren with a detailed clinical and genetic study of a sele: cted group [MDS Thesis] UK: University of London; 1974.

17-Cielucke. O uso de implantes osseointegrados em pacientes em crescimento. [Monografi a apresentada para obtenção do grau de especialista em Implantodontia]. Porto Alegre: ABO RS; 1999.

18-Cronin RJ, Oesterle LJ, Ranly DM. Mandibular Implants and the Growing Patient. J Oral Maxillofac Implants 1993; 9:55-62.

19-Durstberger $\mathrm{G}$ et al. Implant-surgica1 and prosthetic rehabilitation of patients with um1tiple dental aplasia: a clinical report. Int J Oral Maxillofacial Implants 1999; p.417-23.

20-Durstberger $\mathrm{G}$ et al. Handbook of facial growth. 3nd ed. Philadelphia: W B Saunders Company; 1993.

21-Gorlin RJ et al. Oxford Monographs on Medical Genetics. Syndromes of the Head and Neck. 3rd ed. Oxford: Oxford University Press; 1990. n.19.

22-Guckes AD et al. Using endosseous dental implants for patients with ectodennal dysplasia. Jam Dent Assoc 1991; 122:59-62.

23-CAGNANI, A., BARROS, A. M. D. S., SOUSA, L. L. A. D., OLIVEIRA, A. M. G., Zanin, L., \& FLÓRIO, F. M. (2014). Associação entre preferência por alimentos doces e cárie dentária. RGO-Revista Gaúcha de Odontologia, 62(1), 25-29.

24-Holland T et al. Traurna to perrnanent teeth of children, aged 8, 12 and 15 years, in Ireland. J Paediatric Dent 1988; 4:13-6. 
25-Jacobsson $\mathrm{M}$ et al. Tissue-integrated implants in children. Int J Pediatr Otorhinolaryngol 1992; 24:235-43.

26-Johansson G et al. Effects of early placernent of a single tooth irnplant. A case report. Clin Oral Impl Res 1994; 5:48-51.

27-Junge T. Qual deve ser a conduta do ortodontista perante o caso de um paciente de 12 anos de idade que tenha agenesia dos incisivos laterais superiores? Rev APCD 1999; 53(3).

28-Koch $\mathrm{G}$ et al. Consensus conference on oral implants in young patients. Stockholm: Forlagshuset Gothia AB; 1996.

29-Kokich VG. Missing maxillary laterals: Are implants the answer? Presented at the American Association of Orthodontists. 94th Annual Session. April $30 \mathrm{Mav}$ 4. Orlando, 1994.

30-Bauman, J. M., Souza, J. G. S., Bauman, C. D., \& Flório, F. M. (2018). Aspectos sociodemográficos relacionados à gravidade da maloclusão em crianças brasileiras de 12 anos. Ciência \& Saúde Coletiva, 23, 723-732.

31-Lekmon U. The use of osseointegrated implants in growing jaws. Int J Oral Maxillofac Implants 1993; 8:243-4.

32-Lindhe et al. Tratado de periodontia clínica e implantodontia oral. 3a ed. Rio de Janeiro: Guanabara; 1999.

33-Mackie IC et al. Implants in children: a case report. Endod Traumatol 1993; 9:124-6.

34-Malmgren B et al. Orthodontic management of the traumaatised dentition. In: Andreasen JO, Andreasen F. Texbook and Colours Atlas of Traumatic Injuries to the Teeth. Copenhagen: Munksgaard; 1993.

35-Bauman, J. M., Souza, J. G. S., Bauman, C. D., \& Flório, F. M. (2018). Padrão epidemiológico da má oclusão em pré-escolares brasileiros. Ciência \& Saúde Coletiva, 23, 3861-3868.

36-Moyers RE. Mandibular implants and growing patient. Int J Oral Maxillofac Implants 1994; 9:55-62. Proffi t W. Conceitos de crescimento e desenvolvimento. In: Ortodontia Conteporânea. $2 a$ ed. Rio de Janeiro: Guanabara; 1995. p.18-51.

37-Sandór KB et al. Pediatric dental implantology. J Oral Maxillofac Surg 1995; 53(8):22. Sumiya H et al. Osseointegração e reabilitação oclusal. São Paulo: Santos; 1997.

38-Sennerby $L$ et al. A biomechanical and morphometric comparison of titanium implants inserted in rabbit cortical and cancellous bone in rabbits. Int J Oral Maxillofac Implants 1992; 7:62-71.

39-Sennerby $L$ et al. Early tissue response to titanium irnplants inserted in rabbit cortical bone. I. Ligth microscopic observations J Mater Sci Mater Med 1993; 4:240-50.

40-Steenbergue DV. Implantes orais em pacientes comprometidos. Periodontia $20002004 ; 33(3)$.

41-Silman JH. Dimensional changes of dental arches: Longitudinal studies from birth to 25 years. Am J Orthod 1964; 50:824-42. Smith RA et al.

42-Da Silva Marinho, Clarisse et al. Impacto do traumatismo dentário na qualidade de vida de crianças, adolescentes e suas famílias: revisão crítica da literatura. Arquivos em Odontologia, v. 55, 2019. 
43-Spiekermann R. Implantology. Zurich: Color Atlas of Dental Medicine; 1995. p.91-6.

44-Stalblad P et al. Osseointegration in overdenture therapy. Swed Dent J 1985; 28:169-70.

45-Sumya $\mathrm{H}$ et al. Osseointegração e reabilitação oclusal. Considerações Biológicas sobre Osseointegração. São Paulo: Santos; 1997. p.33-53. 462p.

46-Weide SV. Oligodontia. A clinical, radiographic and genetic evaluation [Thesis]. The Netherlands: University of Utrecht; 1992. Wilox D. A critical analysis of osseointegrated implants in children and adolescents. 2003. Disponibilizado em URL: http://www. comptonimplants.com/pdfs/wilcox_davin.pdf [2004 nov]. 